Complaints about the activities of the judiciary exist both among citizens and among representatives of other branches of government, which has an extremely negative impact on the authority of the judiciary, the judiciary itself and the activities of the state as a whole. Ukraine's judicial system is based on trust and respect for it, on confidence in its independence, impartiality and justice.

The problem of non-enforcement of court decisions in Ukraine sharply undermines the authority of the state, because it is a signal of mass violations of human rights, but also causes significant distrust of Ukrainian society to the current government.

Only through the full implementation of court decisions the fundamental principles of the world democratic system are realized: humanism, justice and the rule of law.

An important way to increase trust and respect for the court is to form a legal culture and legal awareness of citizens, a greater understanding of the importance of the court.

It is also important to remember that people who provide court services are the face of justice. They have the greatest influence on the formation of the authority of the judiciary, and consequently trust in it.

It is necessary to introduce verification of candidates in local courts for compliance with the criteria of integrity and professional ethics.

Among the most important tasks facing the judiciary in the state - is to gain the trust of citizens, strengthen their authority and increase social status in society, which will significantly affect the quality of execution of court decisions.

Key words: non-enforcement of court decisions, judiciary, trust in the judiciary, legal awareness.

DOI: $10.36695 / 2219-5521.2 .2020 .49$

УДК 347.9

\title{
А.Г. ГУЛИК
}

\author{
Андрій Григорович Гулик, суддя Львівського \\ окружного адміністративного суду*
}

ORCID: 0000-0001-5390-1812

\section{ФОРМИ ТА СПОСОБИ ОПТИМІЗАЦІї ЦИВІЛЬНОГО СУДОЧИНСТВА}

Постановка проблеми. Оптимізація як явище і наукова категорія сьогодні міцно асоціюється з сучасним життям. Економічне зростання і розширення руху товарів, робіт і послуг вимагають істотної зміни в більшості областей людської діяльності, пошуку балансу між заявленими високими цілями, засобами їх досягнення і вихідними характеристиками такої діяльності. Мабуть, це в певному сенсі і пояснює той факт, що в багатьох сферах виробництва і споживання оперують сьогодні терміном «оптимізація».

Не залишається осторонь і право, як один із відомих регуляторів суспільних відносин. Адже право не завжди встигає за економічними процесами та зростанням, що викликаються ними, за становленням і розвитком суспільства й новими суспільними відносинами, котрі складаються в ньому. Найчастіше воно запізнюються в своєму русі, змушене навздогін шукати правові форми, які б адекватно відображали нові економічні і соціальні зв'язки суб'єктів. І в цьому плані, мабуть, оптимізація являє собою об'єктивно існуюче явище, яке сприяє досягненню намічених цілей шляхом визначення найкращої системи здійснюваних дій. Правомірна постановка питання і про те, що оптимізація в праві - це один із засобів удосконалення регулювання суспільних відносин.

Висловлювані положення в цілому можуть бути вельми застосовні й до цивільного процесуального права та цивільного судочинства як невід'ємного предмета його вивчення. Вивчення оптимізації цивільного судочинства ставить перед дослідником завдання щодо встановлення всіх істотних характеристик даного явища. До числа таких характеристик, безсумнівно, можна віднести питання форм і способів оптимізації.

Аналіз останніх досліджень і публікацій. До проблеми оптимізації цивільного судочинства в аспекті удосконалення цивільного процесуального законодавства зверталися такі провідні вітчизняні вчені-процесуалісти, як: Ю.В. Білоусов, С.С. Бичкова, В.І. Бобрик, Н.Л. Бондаренко-Зелінська, О.В. Гетманцев, К.В. Гусаров, О.В. Дем'янова, І.О. Ізарова, В.В. Комаров, В.А. Кройтор, М.П. Курило, Ю.В. Навроцька, Ю.Д. Притика, Г.П. Тимченко, С.Я. Фурса та інші. Проте так і залишаються малодослідженими питання структурної характеристики оптимізації цивільного судочинства, точніше кажучи, питання форми і способів такої оптимізації.

Мета статті. Мета даної статті полягає в розробленні теоретичних положень щодо основних можливих форм і способів оптимізації цивільного судочинства.

Виклад основного матеріалу. Форма і зміст як парні філософські категорії невіддільні одна від одної. Власне, саме форма обумовлює більш повне розкриття ії змісту. Як зазначає у цьому зв’ язку К.А. Царегородцева, форма, виступаючи зовнішнім вираженням оптимізації, обумовлена її змістом. Вчена пропонує виділяти законодавчу та правозастосовну форми оптимізації цивільного судочинства.

Законодавча форма оптимізації може виражатися як у прийнятті нового процесуального кодексу, реформі законодавства, так і в змінах окремих норм права. Правозастосовна форма оптимізації грунтується насамперед на використанні наявного законодавчого потенціалу в роботі судів щодо здійснення правосуддя. Правозастосовна форма оптимізації можлива на основі аналізу судової практики. Крім того, правозастосовна форма оптимізації виражається і в забезпеченні однаковості правозастосування ${ }^{\text {. }}$

\footnotetext{
(C) А.Г. Гулик, 2020

* Andriy Gulyk, Ph.D. in Law, judge of Lviv District Administrative Court
} 
На правозастосовну форму оптимізації звертає увагу і В.В. Шпак. Дослідник обгрунтовує думку, що крім функцій правосуддя і контролю суди також здійснюють функцію оптимізації цивільного судочинства. Виділення такої функції багато в чому базується на тому положенні, що фактично з урахуванням сформованої правозастосовної практики судовий прецедент має схоже становище 3 джерелом права. Підсумком авторських міркувань стала теза про те, що оптимізація як функція органів судової влади являє собою одну 3 функцій Верховного Суду, змістом якої виступає роз'яснення чинного законодавства на основі даних судової практики з метою подолання наявних колізій і прогалин законодавства для досягнення завдань цивільного судочинства².

Ми солідарні з думками цитованих автора, хоча і з деякими застереженнями. Оптимізація передбачає новелізацію цивільного законодавства або внесення певних змін у вже діючі правила здійснення цивільної процесуальної діяльності. Це можливо лише в результаті проведення законодавчих робіт. Мабуть, це головна форма оптимізації цивільного судочинства. Що ж стосується правозастосовної форми, яку виділяє К.А. Царегородцева, то видається, що вона виступає лише в певному сенс передумовою законодавчої. Використання законодавчого потенціалу в роботі судів пов'язана, головним чином, з належною організацією судової діяльності. Звичайно, велику роль відіграють узагальнення та аналіз судової практики, що дає змогу побачити проблемні аспекти правозастосування, визначити найефективніші шляхи їх вирішення і досягти необхідної єдності судової практики.

Втім, К.А. Царегородцева й сама обмовляється, вказуючи, що оптимізація стосується не тільки вдосконалення процесуального законодавства, процедури розгляду та вирішення справ, а й впровадження організаційно-технічних засобів, котрі допомагають удосконалювати роботу судів. В якості прикладу дослідниця наводить проблему електронного документообігу, використання договорів про електронний цифровий підпис тощо. У автора це так зване широке розуміння оптимізації.

$\epsilon$ ще й вузьке розуміння оптимізації. У цьому контексті, з точки зору К.А. Царегородцевої, оптимізація охоплює вдосконалення інститутів та норм цивільного процесуального законодавства і правозастосовної практики, що дає змогу найкращим чином досягти виконання завдань цивільного судочинства.

У другому випадку оптимізація здійснюється різними способами, до яких можна віднести наступні:

1) вдосконалення усього механізму відправлення правосуддя у цивільних справах;

2) створення та удосконалення окремих інститутів, спеціально спрямованих на оптимізацію судочинства;

3) виявлення та усунення суперечностей у чинному законодавстві;

4) забезпечення однаковості судової практики ${ }^{3}$.

На думку автора, перераховані способи мають єдину мету - забезпечення швидкого та якісного здійснення правосуддя, але вони різняться за сферою свого застосування. У зв'язку з цим способи оптимізації судочинства можна підрозділити на загальні та спеціальні. До загальних способів можна віднести ті, які сприяють оптимізації усього механізму відправлення правосуддя. Спеціальні способи оптимізації - цілеспрямовано створені інститути для прискорення, спрощення процедури розгляду справ 4 .

Продовжуючи авторські міркування в обраному напрямі, К.А. Царегородцева зазначає, що вдосконалення механізму здійснення правосуддя, виявлення суперечностей у чинному законодавстві та відсутність єдності правозастосовної діяльності охоплюють весь процес або його стадії, види судочинства. Вдосконалення процесуального механізму передбачає виявлення окремих інститутів або норм, які в сукупності $є$ гальмом у досягненні цілей судочинства. До загальних способів оптимізації можна віднести: оптимізацію процесуальних строків та оптимізацію стадій цивільного судочинства: порушення справи; підготовка справи; розгляд і вирішення справи по суті; всі види перегляду судових актів.

Водночас оптимізація цивільного судочинства, охоплюючи весь механізм здійснення правосуддя, разом iз тим може стосуватися окремих норм, правових інститутів. Створення і впровадження спеціальних інститутів, спрямованих на прискорення або спрощення процедури судочинства, не передбачає вдосконалення усього механізму судочинства.

Спеціальні способи оптимізації судочинства спрямовані на розробку і впровадження певних засобів прискорення або спрошення процедури розгляду і вирішення цивільних справ судами. До таких спеціально створених способів належать: спрощене провадження; наказне провадження; заочне рішення; примирні процедури; запровадження скорочених строків розгляду справ 5 .

Як бачимо, оптимізація виступає певним інструментарієм оцінки цивільного судочинства, а також можливих напрямів його перетворення. Не викликає сумнівів той факт, що оптимізацію можна вивчати як з позиції стадійності та процесуальної форми здійснення цивільної процесуальної діяльності, так і з позиції реалізації окремих норм та інститутів цивільного права. При цьому процедури примирення та процесуальні строки скоріше можна віднести до загальних положень цивільного процесу, у зв'язку з чим їх віднесення до спеціальних способів оптимізації досить дискусійне.

К.А. Царегородцева має рацію в тому, що оптимізацію не можна зводити виключно до спрощення та прискорення цивільного процесу. Як не можна зводити вдосконалення цивільного процесуального законодавства лише до його прискорення й спрощення. Хоча автор далі і допускає змішання цих категорій, вважаючи, що оптимізація складається 3 гармонійного поєднання продуманості процесуальних норм і гнучкості процесуальної форми з метою прискорення досягнення цілей судочинства. Це прискорення може досягатися шляхом спрощення процесу, надання йому гнучкості, налагодженості усього механізму, прагнення до однаковості практики 6 .

Не обходить даний дослідник і питання співвідношення оптимізації та ефективності. Підкреслюючи тісний зв'язок ефективності та оптимізації, автор розглядає ефективність цивільного судочинства як міру 
відповідності правової реальності нормам права, а оптимізацію - як сукупність засобів, що забезпечують найбільш швидке і легке досягнення цілей судочинства. Оптимізація цивільного судочинства - це шлях до підвищення його ефективності7.

Розділяючи багато в чому зазначені аспекти форм і способів оптимізації цивільного судочинства, тим не менш, висловимо низку загальних положень, що мають відношення до розглянутої проблеми. Однак спочатку зазначимо, що методологічним підгрунтям тут стануть підходи, розроблені Х.А. Джавадовим стосовно аналізу ефективності цивільного судочинства ${ }^{8}$.

Вважаємо, що вони можуть бути затребувані і при осмисленні проблематики оптимізації цивільного процесу.

Оптимізацію слід розглядати як складну і комплексну правову категорію. Можна вивчати в цілому порядок розгляду і вирішення цивільних справ або сконцентрувати свою увагу на більш вузьких питаннях змісту окремих стадій або проваджень. Не виключена увага до питань формування адекватної судової практики 3 цивільних справ. Будь-який зріз цивільної процесуальної діяльності можна вивчати з позиції оптимізації.

У цьому зв'язку правомірно ставити питання про систему теоретичних поглядів на оптимізацію цивільного процесу, які відображають структуру цивільного судочинства. Розглядаючи оптимізацію цивільного судочинства як загальний напрям наукового пошуку, в його межах можуть бути досліджені питання оптимізації окремих стадій та проваджень цивільного процесу. Або навпаки, осмислення діяльності суб'єктів цивільного процесу можна проводити крізь призму ії оптимізації. Так само, як і аналіз процесуальних засобів забезпечення реалізації завдань цивільного судочинства можливий за допомогою дослідження оптимізації. Тобто ми бачимо досить широке застосування категорії, що розглядається.

Висновки. Проведене дослідження дає підстави для висновку, що оптимізація виступає певним інструментарієм оцінки цивільного судочинства, а також можливих напрямів його змін. Це можливо лише в результаті проведення законодавчих робіт. Мабуть, це - головна форма оптимізації цивільного судочинства. Що ж стосується правозастосовної форми, то видається, що вона виступає лише в певному сенсі передумовою законодавчої. Використання законодавчого потенціалу в роботі судів пов'язана передусім з належною організацією судової діяльності. Звичайно, велику роль відіграють узагальнення та аналіз судової практики, що дає змогу побачити проблемні аспекти правозастосування, визначити найефективніші шляхи їх вирішення i досягти необхідної єдності судової практики.

Оптимізацію важливо вивчати як з позиції стадійності та процесуальної форми здійснення цивільної процесуальної діяльності, так і з позиції реалізації окремих норм та інститутів цивільного права. Правомірно ставити питання про систему теоретичних поглядів на оптимізацію цивільного процесу, які відображають структуру цивільного судочинства. Розглядаючи оптимізацію цивільного судочинства як загальний напрям наукового пошуку, в його межах можуть бути досліджено питання оптимізації окремих стадій та проваджень цивільного процесу. Або навпаки, осмислення діяльності суб'єктів цивільного процесу можна проводити крізь призму їі оптимізації. Так само, як і аналіз процесуальних засобів забезпечення реалізації завдань цивільного судочинства можливий за допомогою дослідження оптимізації.

${ }^{1}$ Царегородцева Е.А. Способы оптимизации гражданского судопроизводства: дисс. ... канд. юрид. наук. Екатеринбург, 2006. C. $51-52$.

2 Шпак В.В. Оптимизация гражданского судопроизводства: дисс. ... канд. юрид. наук. Саратов, 2019. С. 31, $35-36$.

3 Царегородцева Е.А. Способы оптимизации гражданского судопроизводства: дисс. ... канд. юрид. наук. Екатеринбург, 2006. C. 52.

4 Там само. С. 52-53.

5 Там само. С. $53-54$

6 Там само. С. 54.

7 Там само. С. $55-56,58$

8 Джавадов Х.А. Проблеми ефективності цивільного судочинства. Київ: Вид-во «Юридична думка», 2018. С. $32-33$.

\section{Резюме}

Гулик А.Г. Форми та способи оптимізації цивільного судочинства.

Стаття присвячена дослідженню форм та способів оптимізації цивільного судочинства.

Обгрунтовується, що оптимізація виступає певним інструментарієм оцінки цивільного судочинства, а також можливих напрямів його змін. Аргументується, що головна форма оптимізації цивільного судочинства - це проведення законодавчих робіт.

Доводиться, що з точки зору способів оптимізацію необхідно розглядати як з позиції стадійності та процесуальної форми здійснення цивільної процесуальної діяльності, так і з позиції реалізації окремих норм та інститутів цивільного права. Автор вважає, що в межах вивчення оптимізації цивільного судочинства можуть бути розглянуті питання оптимізації окремих стадій та проваджень цивільного процесу. Крім того, осмислення діяльності суб'єктів цивільного процесу також необхідно проводити крізь призму іiі оптимізації та ефективності. Так само, як і аналіз процесуальних засобів забезпечення реалізації завдань цивільного судочинства можливий за допомогою дослідження оптимізації.

Ключові слова: оптимізація цивільного судочинства, форми оптимізації, способи оптимізації, цивільна процесуальна форма, судові процедури.

\section{Резюме}

Гулик А.Г. Формы и способы оптимизации гражданского судопроизводства.

Статья посвящена исследованию форм и способов оптимизации гражданского судопроизводства. Обосновывается, что оптимизация выступает в качестве определенного инструментария оценки гражданского судопроизводства, а также возмож- 
ных направлений его изменений. Аргументируется, что главной формой оптимизации гражданского судопроизводства является проведение законодательных работ по совершенствованию гражданского процессуального законодательства.

Доказывается, что с точки зрения способов оптимизацию необходимо рассматривать как с позиции стадийности и процессуальной формы осуществления гражданской процессуальной деятельности, так и с позиции реализации отдельных норм и институтов гражданского процессуального права.

Автор считает, что в пределах изучения оптимизации гражданского судопроизводства могут быть рассмотрены вопросы оптимизации отдельных стадий и производств гражданского процесса. Кроме того, осмысление деятельности субъектов гражданского процесса также необходимо проводить сквозь призму ее оптимизации и эффективности. Так же, как и анализ процессуальных средств обеспечения реализации задач гражданского судопроизводства возможен с помощью исследования проблем оптимизации.

Ключевые слова: оптимизация гражданского судопроизводства, формы оптимизации, способы оптимизации, гражданская процессуальная форма, судебные процедуры.

\section{Summary}

Andriy Gulyk. The forms and methods of optimization of civil procedure.

The article covers structural characteristics of optimization of civil procedure. It is noted that the study of optimization of civil procedure determines the establishment of all essential characteristics of this phenomenon. Among them, undoubtedly, one should refer to the issues of forms and methods of optimization.

It is substantiated that optimization involves the novelization of civil procedural legislation or certain amendments to the rules in force of carrying out civil procedural activities. It is possible only as a result of legislative work. This is the main form of optimization of civil procedure.

It is proved that judicial enforcement is a prerequisite of the legislative form of optimization. In this case, generalization and analysis of judicial practice play an important role, allowing discerning the problematic aspects of law enforcement, determining the most effective ways to resolve the relevant problems and achieving the necessary unity of judicial practice.

It is argued that optimization is a certain instrumentarium for assessing civil procedure, as well as possible directions for its transformation. It is emphasized that optimization should be studied both from the perspective of stages and procedural form of carrying out civil procedural activities, and from the perspective of implementing certain norms and institutions of civil procedural law. At the same time, the author relates the conciliation procedures and procedural periods to the general provisions of civil procedure rather than to special optimization methods.

It is substantiated that optimization, as well as improvement of civil procedural legislation, cannot be reduced solely to simplification and acceleration of civil procedure.

The author considers optimization of civil procedure as a complex legal category. It is noted that it is right to study the procedure for the consideration and resolution of civil cases in general or to concentrate on the narrower issues of the content of particular stages or proceedings. Attention may also be paid to issues of the formation of adequate judicial practice in civil cases. It is important to study any section of civil procedural activity from the perspective of optimization.

The author believes that within the framework of studying optimization of civil procedure, issues of optimization of particular stages and proceedings of civil procedure can be considered. Moreover, the comprehension of the activities of subjects of civil proceedings also needs to be carried out in the light of of its optimization and efficiency. In the same way, the analysis of the procedural means of ensuring the realization of the task of civil procedure is possible through the study of optimization problems. cedures.

Key words: optimization of civil procedure, forms of optimization, methods of optimization, civil procedural form, judicial pro-

DOI: 10.36695/2219-5521.2.2020.50

УДК 336.64:629.5

\section{І.О. ДАНИЛОВА}

Ірина Олександрівна Данилова, старший викладач Навчально-наукового морського Гуманітарного інституту Одеського національного морського університету*

ORCID: 0000-0002-3174-477X

\section{ЩОДО ОКРЕМИХ ІСТОРИКО-ПРАВОВИХ ПЕРЕДУМОВ СТАНОВЛЕННЯ I РОЗВИТКУ ТРАНСПОРТНОГО ПРАВА}

Постановка проблеми. Ефективне правове забезпечення правовідносин, що складаються в царині транспортного права на сучасному етапі державотворення, неможливе без історичного огляду передумов становлення й розвитку транспортного права як комплексної галузі права. Окремої школи транспортного права ні в колишньому СРСР, ані в Україні не було утворено, тому сьогодні дослідження проблем транспортного права і розробку пропозицій з іх подолання здійснюють вчені, які належать до наукових шкіл господарського, цивільного та адміністративного права.

(C) І.О. Данилова, 2020

* Iryna Danilova, Seniour Lecturer of the Primary Nautical Humanitarian Institute of Odessa National Maritime University 